Sustinere

Journal of Environment and Sustainability

Volume 2 Issue 3 (2018) 144-155

Print ISSN: 2549-1245 Online ISSN: 2549-1253

Website: https://sustinerejes.comE-mail:sustinere.jes@iain-surakarta.ac.id

\title{
RESEARCH PAPER \\ Preliminary research on environmental literacy and conservation toward eco-tourism through the community learning centre
}

\author{
Budiyono Saputro ${ }^{*}$, Fadhil Ardhiansyah ${ }^{2}$ \\ 1. Dept. of Science Education, Institut Agama Islam Negeri Salatiga, Salatiga, Indonesia \\ 2. Postgraduate Programme of Universitas Negeri Semarang, Indonesia \\ Article history: \\ Received 7 August 2018 | Accepted 7 December 2018 | Available online 31 December 2018
}

\begin{abstract}
Coastal abrasion has caused the destruction of the mangrove forest in Mojo Pemalang Village. Thus, a preliminary study of communities' literacy about conservation at Mojo Village, Pemalang, was required to develop the potential of mangrove forest ecotourism. This study aimed to understand the fishermen's literacy about conservation at Mojo Village, Pemalang related with the development of mangrove forest ecotourism through the Community Learning Center (CLC). The type of research was qualitative descriptive. The research subjects were fishermen in Mojo Village, Pemalang, Central Java, Indonesia. The results of a preliminary study of six indicators of environmental literacy and conservation developed by the North American Association for Environmental Education (2011) and Rush et al. (1999) are as follows: ecological knowledge $=6.02 \%$, verbal commitment $=6.02 \%$, environmental sensitivity $=6.02 \%$, identification $=12.04 \%$, issue analysis $=6.02 \%$, and real commitment $=$ $6.02 \%$. The overall percentage was $42.14 \%$ and was included in the low category. The results of the preliminary study indicated that Mojo fishing communities' literacy about conservation of the environment towards mangrove forests still needed to be improved. A solution suggested based o the results of a preliminary study was the implementation of mangrove ecotourism Community Learning Center (CLC), conducted through several pieces of training, including conservation training, education training, tourism training, and economic training.
\end{abstract}

Keywords: community learning; environmental conservation; environmental literacy

\section{Introduction}

Literacy education and environmental conservation are very important for the community to maintain and improve the attention for the preservation of the surrounding environment. After Indonesia participated in the 1972 United Nations conference on the environment in Stockholm, the implementation of development began to consider its impacts on the environment (Tumisem, 2012). Related with that, supported by the Law No. 4 of 1982 concerning Basic Provisions for Environmental Management, the government issued official 
rules governing environmental preservation. Article 9 of Law No. 4 of 1982 states that the government has an obligation to grow and develop public awareness about the responsibility to manage the environment through counselling, guidance, education and research on the environment (the Republic of Indonesia, 1987).

Based on these regulations, it is necessary to have community service to bridge activities in preserving the environment. One of them is the Community Learning Center (CLC). This service cannot stand alone, yet there must be the involvement of the targeted parties (Hiryanto, 2009). The focus of this article was the literacy and environmental conservation in the fishing community of Mojo Village, Ulujami District, Pemalang through CLC of mangrove forest ecotourism tailored to the characteristics and potential of human resources in Mojo Village (Purnamawati et al., 2015; Saraswati, 2004). Empowerment can be developed through education (Hiryanto, 2008). To determine the suitable Community Learning Center (CLC) for the Mojo mangrove forest ecotourism area, it was necessary to conduct a preliminary study.

\section{Literature review}

\subsection{Profile of Mojo Village Community, Ulujami District, Pemalang Regency}

Mojo Village is located in Ulujami District, Pemalang Regency, Central Java. Geographically, Pemalang is located between 109o 17 '30' '109o East Longitude and 40' 30 " East Longitude and between 06052 '30' 'South Latitude and 7o 20' 11 "South Latitude. It is bordered by Pekalongan Regency in the east, Tegal Regency in the west, the Java Sea in the north, and Purbalingga or Banyumas in the north (Saraswati, 2004). The area of Pemalang Regency is approximately 113,271 hectares. It has a tropical climate with an average temperature of 26.05 ${ }^{\circ} \mathrm{C}$ with alluvial soil or land resulted from the deposition of lowland river mud in various subdistricts, one of them is Ulujami. Mojo Village, Pemalang Regency has natural resources e.g. beaches and mangrove forests as can be seen in Figure (Suryani et al., 2015).

The land area for rice fields was 11,843 hectares and for non-rice fields was 42,936 hectares (BPS Pemalang, 2017). Meanwhile, land use for ponds was 32.72 hectares and the rest was 2.05 hectares.

According to BPS data in 2017, the total population of Mojo Village in Ulujami District was 8,036 . They are distributed into five age groups i.e. 3639 men and 3836 women were aged 4549, 3322 men and 3520 women were aged 50-54, 2973 men and 2945 women were aged 55-59, and the age group of $>60$ consisted of 7512 men and 8248 women. Most of Mojo villagers work as fishermen (875 people) and farmers (1294 people). Others are industrial workers ( 131 people), farm workers ( 860 people), construction workers ( 1215 people), traders (498 people), transportation workers (48 people) and the rests (1820 people). 


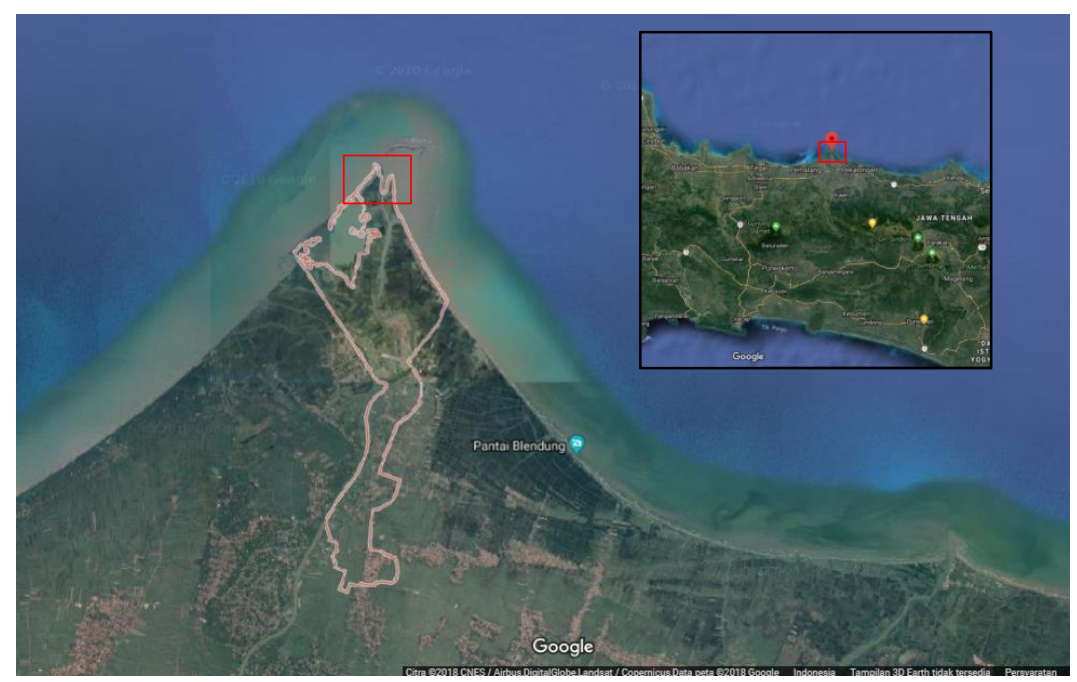

(a)

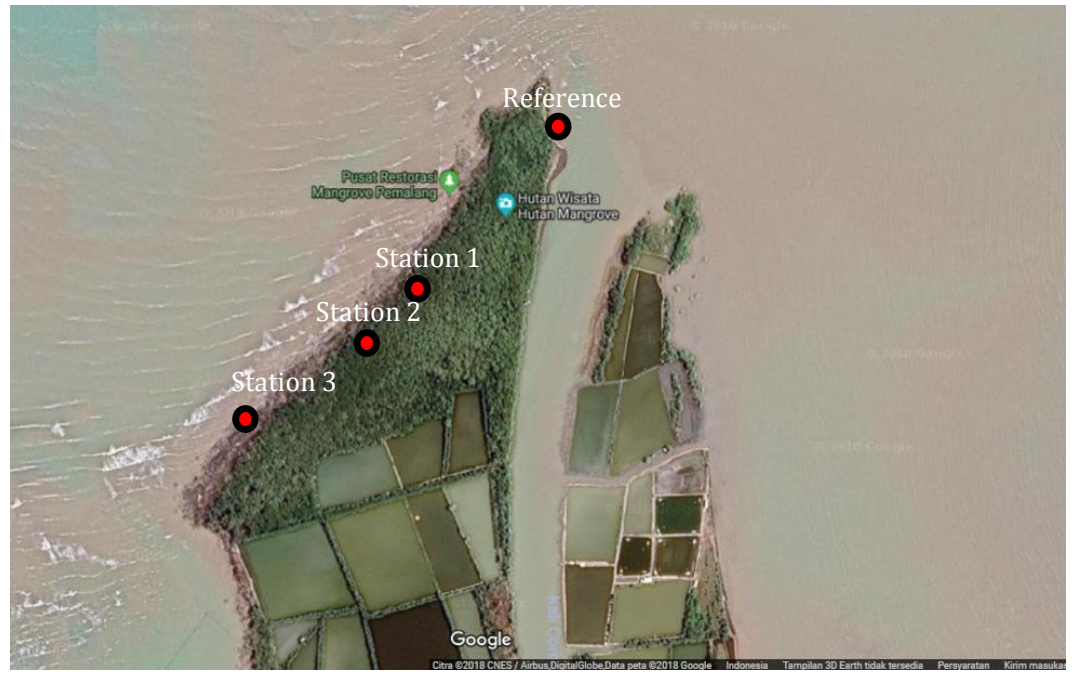

(b)

Figure 1. Map of the research location. (a) Location of Mojo Village, Ulujami District, Pemalang District, Central Java. (b) Mojo Beach and Station 1-3 locations are Mojo Mangrove Forests.

Data from BPS about Pemalang Regency (2017) mentioned that 30\% of the total population of Mojo Village graduated from elementary education level, 55\% graduated from secondary education level, and 15\% graduated from higher education level.

\subsection{Environmental literacy and conservation}

Indonesia is in the $62^{\text {nd }}$ rank among 72 countries in the world regarding the quality of its education. This data was taken from the survey of the International Student Assistance Program (PISA) (Sidharta, 2017). This shows that the quality of education in Indonesia was still low in the fields of natural sciences, reading, and mathematics. The quality of education can be improved if the teacher has the ability to equip students with scientific ideas. This is in accordance with the opinion of Bybee et al. (2009) stating that the purpose of PISA is to apply one's knowledge in relevant contexts to develop their interest supporting them for scientific inquiry. 
Environmental education helps students to be environmentally literate (Saribas, 2015). Someone is said to be environmentally literate if he/she is aware of what has been done and what to do for the environment (Hollweg et al., 2011). Measuring a person's environmental literacy is the analysis of some criteria including knowledge, attitudes, cognitive skills, and responsibility in the environment (Hollweg et al., 2011 and Rush et al., 1999). Environmental literacy can be represented by some activities conducted by the community that could save the environment. The study conducted by Njurumana (2007) showed that community-based soil and water conservation could increase land productivity, environment and income.

\subsection{Community Learning Center (CLC)}

The implementation of the Community Learning Center (CLC) model for mangrove ecotourism also focused on the knowledge and practice of Mojo fishing communities in managing and preserving the surrounding environment. The Community Learning Center (CLC) model of mangrove ecotourism in general according to Jayagoda (2015) and Zalukhu (2012) consisted of five forms, namely preservation, education, tourism, economy and the participation of the surrounding community.

The first model was conservation activities. This activity was expected not to cause damage to the living things and pollute the environment. One way to implement it was to carry out regular planting by considering some unexpected conditions that occur in mangrove forests and holding the environmentally friendly principle and involving the surrounding community for the management.

The second model of the Community Learning Center (CLC) was education. This activity was carried out by giving knowledge to the surrounding community by utilizing internet media as a mean of communication to public audiences represented by digital-based environmental literacy and conservation

The third CLC activity was tourism. In this aspect, an activity must contain elements of pleasure to motivate tourists to visit a location such as the adequate infrastructure or facilities.

The fourth activity of Community Learning Center (CLC) was in an economic sector that is expected to open business opportunities for surrounding communities especially if tourism trips are carried out with the support of local resources, such as transportation, accommodation and high-qualified guide services.

The fifth type of Community Learning Center (CLC) was the participation of the surrounding community. This can be grown by increasing the understanding of the form of literacy on the environment and its conservation by developing the critical thinking skill of the communities. As the result, they will be more sensitive to the environment and able to manage and utilize mangrove forest resources.

In facilitating community learning, the Community Learning Center (CLC) has several functions including to identify community needs, organize educational programs, provide potential resources, build cooperation with partners, monitor and evaluate programs, alternative education, information and sources of learning resources, and community development (Septiani, 2015). 


\section{Methodology}

This is qualitative descriptive research. The study intentionally selected ten fishermen from Mojo Pemalang, Indonesia, as respondents. Data were obtained from the pretest in the form of descriptive questions with indicators of ecological knowledge, verbal commitment, environmental sensitivity, identification, issue analysis and real commitment. Data of the preliminary study in the form of Likert scale scores were analyzed using percentage techniques. The qualitative data analysis using the interactive model was divided into three stages (Huberman, 1992) i.e. data reduction, data presentation and conclusions or verification. The data reduction was a stage that sharpens, classifies, directs, removes unnecessary, and organizes data in such a way that the final conclusions could be drawn and verified. While the data presentation structured information drew conclusions and gave possible solutive actions.

\section{Results and discussions}

The pretest given to respondents was in the form of a problem description in accordance with the instrument developed by the North American Association for Environmental Education (Hollweg et al., 2011) and Rush et al (1999). The results of the preliminary study of six indicators regarding the form of literacy and environmental conservation in Mojo fishing communities are shown in Table 1.

Table 1. The results of a preliminary study of six indicators of environmental literacy and conservation

\begin{tabular}{lc}
\hline Indicator & Result \\
\hline Ecological knowledge & $6.02 \%$ \\
Verbal commitment & $6.02 \%$ \\
Environmental sensitivity & $6.02 \%$ \\
Identification & $12.04 \%$ \\
Issue analysis & $6.02 \%$ \\
Real commitment & $6.02 \%$ \\
\hline Total & $42.14 \%$ \\
\hline
\end{tabular}

Based on table 1, the total percentage of the data from the preliminary study of literacy pretest and environmental conservation of Mojo village fishermen communities was $42.14 \%$ on a $100 \%$ maximum scale. This percentage was included in the low category. Referring to each indicator, the highest percentage was on identification aspect $(12.04 \%)$ while the lowest ones were the ecological knowledge, verbal commitment, environmental sensitivity, issue analysis and real commitment with the percentage of each of $6.02 \%$. The identification got the highest percentage because respondents showed the good ability to understand the environment of the local mangrove forest ecotourism.

Responding to the results of the preliminary study, it was necessary to develop a method to improve the literacy and environmental conservation of mangrove ecotourism for the fisher communities of Mojo Village. The method is the mangrove forest ecotourism Community Learning Center (CLC) through the following activities: 
- Environmental conservation training.

In this training activity, the Mojo Village fisher communities were introduced about the characteristics of the resources found in Mojo Mangrove forest ecotourism. Forms of preservation introduced in the training included: planting appropriate crops, maintaining the location of mangrove ecotourism and training in making dykes.

Environmental preservation of mangrove ecotourism in Mojo Village could be conducted by planting plants suitable for their habitat. According to the study by Purnamawati et al. (2015), Avicenna marina and Rhizopus mucronata are two plants possibly developed in Mojo mangrove forest ecotourism. The picture of the two plant seeds is shown in Figure 2.

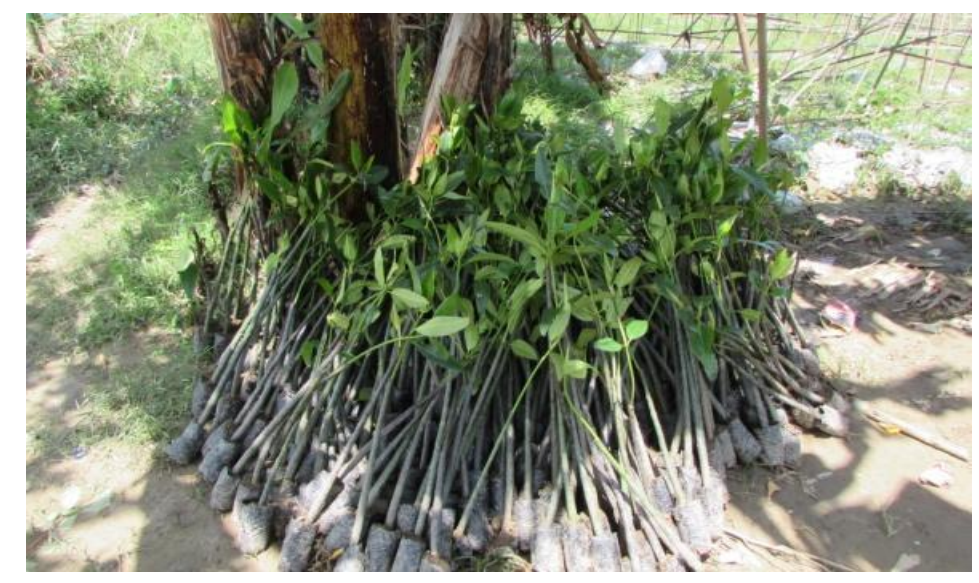

Figure 2. Seeds of Avicenna marina and Rhizophora mucronata

Environmental preservation can also be done by maintaining the location of mangrove ecotourism. This activity is carried out by cleaning and managing conservation-based waste. The potential waste can be managed with the method as shown in Figure 3.

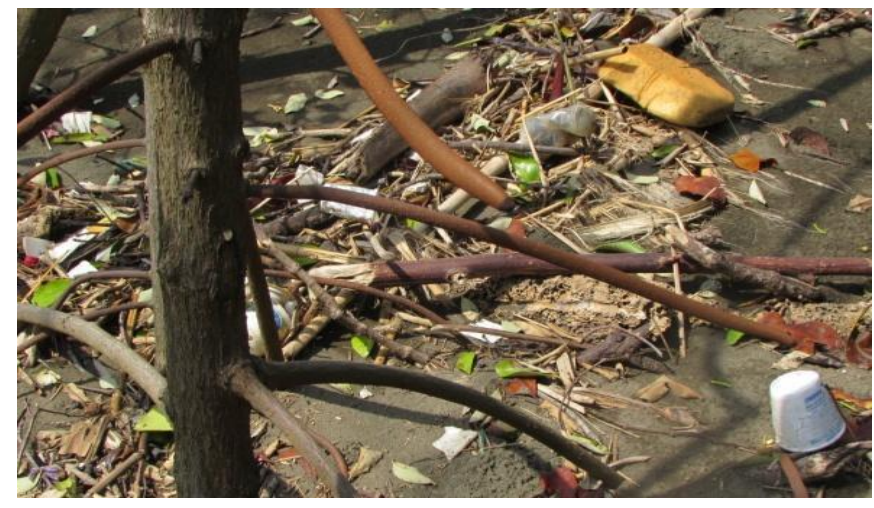

Figure 3. Ecotourism waste of potential mangrove forests is managed based on conservation 
While training in the construction of abrasion prevention dykes that could damage the mangrove forest ecosystem by considering the economic aspects was easily implemented by the fishing communities of Mojo Village. Abrasion condition is shown in Figure 4.

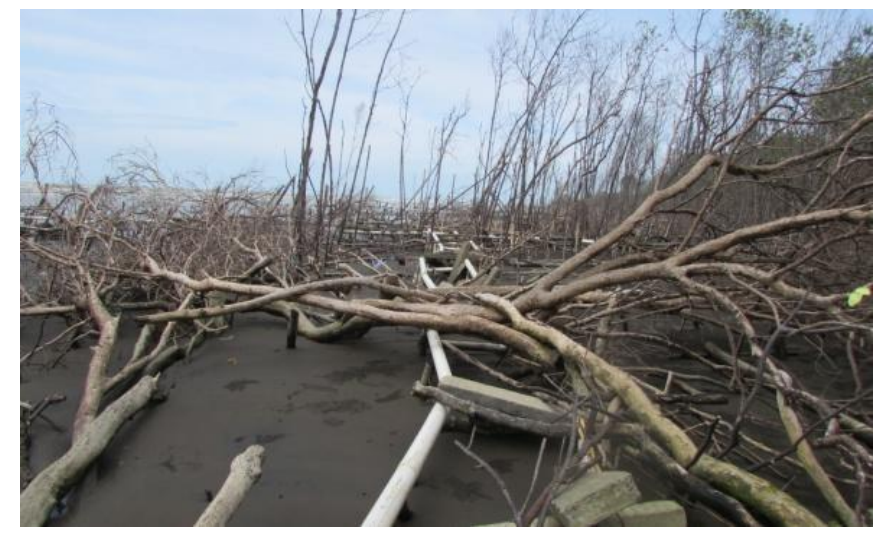

Figure 4. Coastal abrasion damaged the mangrove forest ecosystem

As a result of the conservation training, the knowledge of the Mojo Village fishing community on ecological aspects, environmental sensitivity, issue analysis and real commitment was formed. This was in line with the opinion of Jayagoda (2015) and Tumisem (2012) regarding activities that could foster environmental and conservation literacy i.e. selecting plants to grow by considering their characteristics and the surrounding environment, as well as considering the importance of conservation by paying attention to existing resources and utilizing them economically and efficiently.

- Educational science and technology.

In this training, the Mojo Village fishing community would be taught the use of science and technology e.g. creating website and e-book about sustainable tourism development and training of local guides using national languages. In this case, we made a website and e-book to describe the overall resources of the Mojo mangrove forest ecotourism and the characteristics of Mojo Village fishermen in preserving the environment. Meanwhile, the training of local guides with the national language was important to carry out because there were still many fishing communities in Mojo Village only understood local languages so that information on animal welfare was poorly understood. For those who were experiencing progress, additional training was provided in the form of English language class preparing them to be more ready welcoming foreign visitors. From the training, the knowledge of the Mojo Village fishing community on ecological aspects, verbal commitment, environmental sensitivity, issue analysis and identification could be developed with the characteristics of environmental literacy and forms of conservation in the digital era.

- Tourism training.

Activities in this training focused on the improvement and development of infrastructure that could support the concept of mangrove forest ecotourism. The tourism training included the creation of a mangrove reading park and writing training. Mangrove reading 
parks were made in the dock area. The reading park, in addition to increasing the knowledge of the surrounding community, would also be an attraction that could distinguish mangrove forest tourism in other regions. Figure 5 is a potential location for the establishment of a mangrove forest ecotourism reading park.

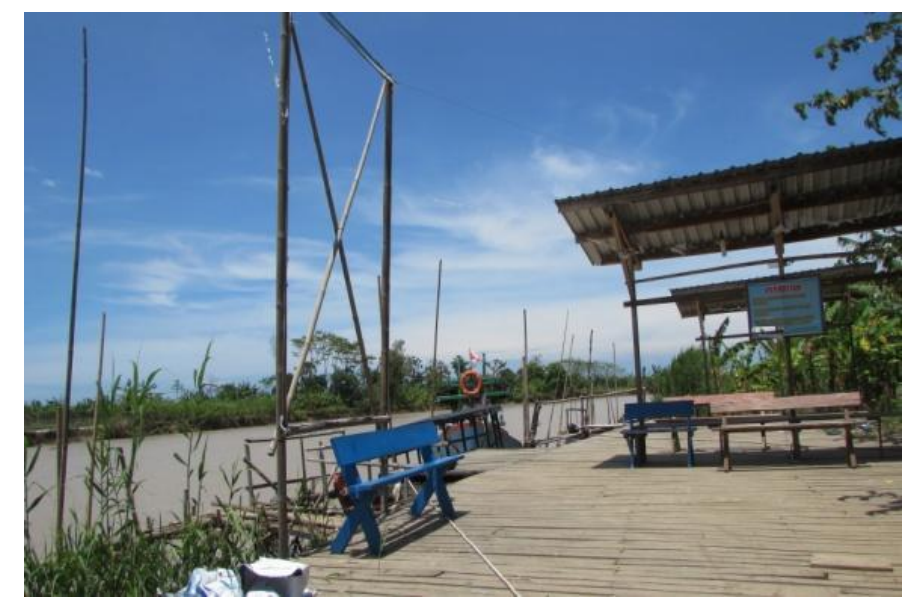

Figure 5. Location of Establishment of Mangrove Forest Ecotourism Reading Park.

Another strategy to support the sustainable ecotourism was by depicting the local and scientific names, descriptions and benefits of each of the resources available in mangrove forests. Figure 6 shows one of name boards that potentially improved mangroves and animals in mangrove forests.

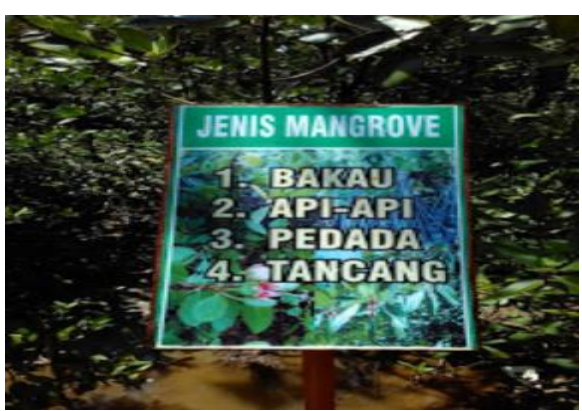

(a)

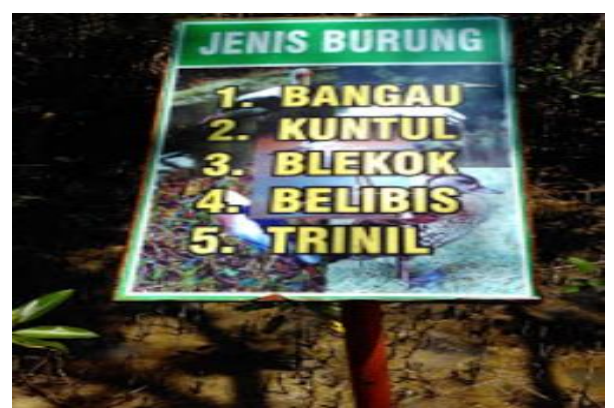

(b)

Figure 6. Samples of Mangrove and Bird Information Boards

After conducting the tourism training, the knowledge of the Mojo Village fishing community on all aspects of literacy and environmental conservation was successfully developed. This was supported by the availability of the mangrove reading park and the writing boards which provided both printed and electronic information about the management and utilization of mangrove forest resources freely accessed by anyone, 
especially the Mojo fishing community in developing and training environmental literacy and forms of conservation.

- Economic training.

In this training, activities focused on entrepreneurship- integrating the concepts of living things both plants and animals that are produced to be valuable goods by the fishing communities of Mojo Village, for example making syrup from the Avicenna marina. Figure 8 is an Avicenna marina fruit that can be produced as syrup. Another business training was the production of terrarium from surrounding plastic waste. Figure 9 is the use of plastic waste around the mangrove forest.

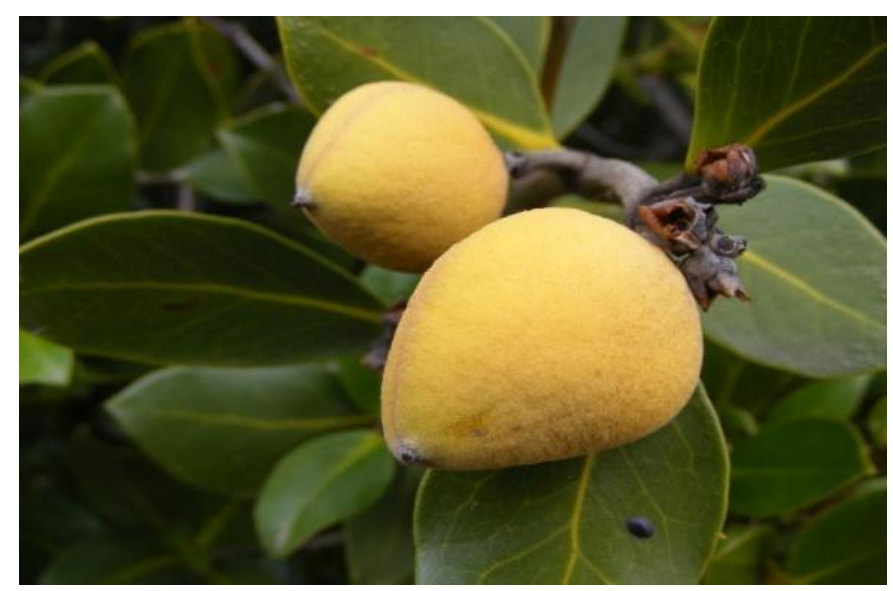

Figure 8. Raw syrup from the Avicennia marina plant.

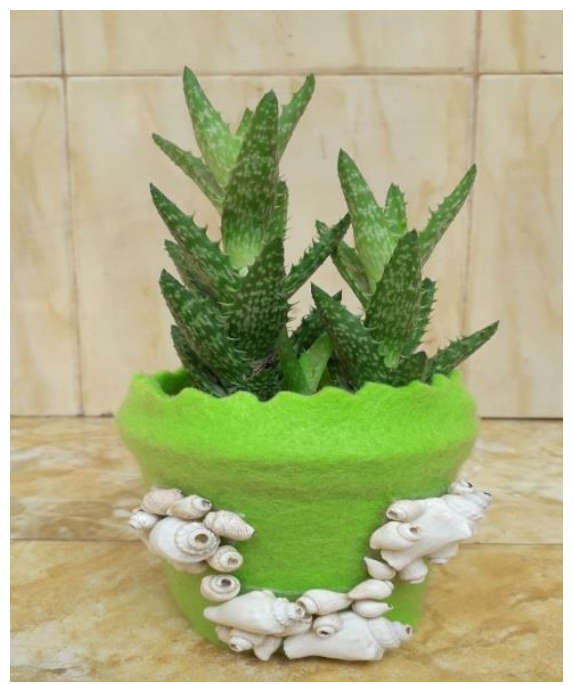

Figure 9. Terrarium of plastic waste on Ecotourism of Mojo Mangrove Forest.

Souvenirs representing the characteristics of the Mojo mangrove forest ecotourism produced by bioplastics are shown in Figure 10. Through this bio entrepreneurship-based economic training, the ecological aspects, which in this case was the attention to and 
utilization of the resources around the mangrove ecotourism, could be developed by the fishing community of Mojo Village. In addition, the aspect of environmental sensitivity was more successfully achieved because the fishing communities of Mojo Village were required to be more critical and creative in making products based on available living things by preserving and conserving the surrounding environment.

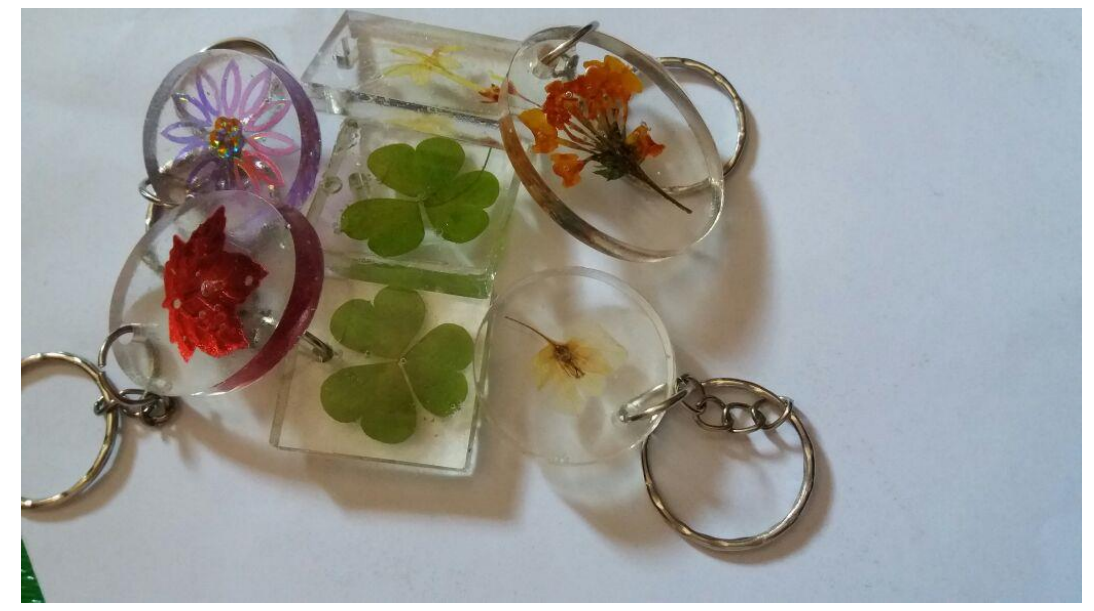

Figure 10. Artificial bioplastics from the Mojo Mangrove Forest.

Strategies to increase the fishermen's literacy and conservation of the environment of Moalang Pemalang Indonesia with the Community Learning Center (CLC) were consistent with Irmawati's research (2017) finding that the role of Community Learning Centers (PKBM) in Karimun was very important in reducing illiteracy. This was indicated by a large number of adult participants taking part in Package A, B, and C literacy programs, as well as the Independent Business Literacy. Moreover, children showed greater participation in Play Groups and Early Childhood Education. The conclusion from Irmawati's (2017) study stated that the role of the Community Learning Center was very important to reduce the illiteracy in Karimun District. This was because the learning schedule in the Community Learning Center was more flexible than formal schooling. The obstacles to the implementation of the Community Learning Center in Karimun included the packed working hours of the residents, the distance, the limited number of tutors and the amount of tutor fees. This was supported by the results of research by Sari et al. (2014) indicating that the management of the Center for Community Learning Activities was effective.

\section{Conclusions}

Based on the preliminary study investigating six indicators of environmental literacy and conservation in the fishing communities of Mojo Village, Pemalang, Central Java, Indonesia, those aspects still needed to be improved because they were classified in the low category. Some indicators that really needed to be considered were: ecological knowledge, verbal commitment, environmental sensitivity, issue analysis and real commitment. The results of the preliminary study showed that the ecological knowledge $=6.02 \%$, (2) verbal commitment $=6.02 \%$, (3) environmental sensitivity $=6.02 \%$, (4) identification $=12.04 \%$, (5) issue analysis $=6.02 \%$, and (6) real commitment $=6.02 \%$ with a total overall percentage of $42.14 \%$. Therefore, the Community Learning Center (CLC) was developed to increase knowledge of literacy and 
environmental conservation in the fishing communities of Mojo Village. The Community Learning Center (CLC) activities included: preservation training, education training, tourism training, and economic training.

\section{Acknowledgement}

Our thanks went to the local government of Pemalang Regency, Ulujami Sub-District Head, Mojo Village Head and fishing communities for their help to provide us with information and data needed in this research.

\section{References}

BPS Pemalang. (2017). Kecamatan Ulujami Dalam Angka 2017. Pemalang: BPS Pemalang.

Hiryanto. (2008). Pemberdayaan Masyarakat Melalui Pendidikan Nonformal. In Lokakarya Pemberdayaan Masyarakat dalam Pendidikan Luar Sekolah, 22 November 2008. Bantul: Badan Perencanaan Pembangunan Daerah (Bappeda) Kabupaten Bantul.

Hiryanto. (2009). Strategi Pengelolaan dan Pengembangan Pusat Kegiatan Belajar Masyarakat. Yogyakarta: PLS FIP Universitas Negeri Yogyakarta.

Hollweg, K. S., Taylor, J. ., Bybee, R. ., Marcinkowski, T. ., McBeth, W. ., \& Zoido, P. (2011). Developing a Framework for Assessing Environmental Literacy. Washington: North American Association for Environmental Education.

Huberman, M. (1992). Analisis Data Kualitatif: Buku Sumber Tentang Metode-Metode Baru. Jakarta: UI Press.

Irmawati, A. (2017). Peran Pusat Kegiatan Belajar Masyarakat (PKBM) dalam Mengurangi Buta Aksara di Kabupaten Karimun. Jurnal Pendidikan Dan Kebudayaan, 2(1), 81-98.

Jayagoda, D. D. (2015). Community-based Mangrove Forest Management in Association with Sustainable Tourism in Puerto Princesa City of the Philippines. International Journal of Sustainable Future for Human Security, 3(2), 23-30.

Njurumana, G. N. (2007). Konservasi tanag dan air berbasis masyarakat di Nusa Tenggara Timur: Studi kasus di Desa Ramuk, Kabupaten Sumba Timur. Jurnal Penelitian Hutan Dan Konservasi Alam, IV(1), 25-39.

Purnamawati, A. D., Saputra, S. W., \& Wijayanto, D. (2015). Nilai ekonomi hutan mangrove di Desa Mojo Kecamatan Ulujami Kabupaten Pemalang. Diponegoro Journal of Maquares, 4(3), 204-213.

Republik Indonesia. Undang-Undang Republik Indonesia Nomor 4 Tahun 1982 Tentang Ketentuan-Ketentuan Pokok (1987). Indonesia.

Rush, M., Whrfe, L., Collins, H., Thomas, K., R, C., \& Blakeley, J. (1999). Towards a Set of Principles for Effective Environmental Education Strategies and Programmes and Their Evaluation. Wellington: Agriculture New Zealand Ltd.

Saraswati, A. A. (2004). Konsep Pengelolaan Ekosistem Pesisir (Studi Kasus Kecamatan Ulujami, Jawa Tengah). Jurnal Teknologi Lingkungan P3TL-BPPT, 5(3), 205-211.

Sari, T. I., Sasongko, R. N., \& Rohiat, R. (2014). Analisis efektifitas pengelolaan pusat kegiatan 
pembelajaran masyarakat (PKBM) (Studi evaluatif di PKBM Sriwijaya Sawah Lebar Kota Bengkulu). Universitas Bengkulu.

Saribas, D. (2015). Investigating the Relationship between Pre-Service Teachers' Scientific Literacy, Environmental Literacy and Life-Long Learning Tendency. Science Education International, 26(1), 80-100.

Septiani, M. (2015). Pengalaman Pusat Kegiatan Belajar Masyarakat (PKBM) dalam Memfasilitasi Masyarakat Belajar Sepanjang Hayat. Jurnal Ilmiah Visi PPTK PAUDNI, 10(2), 67-76.

Suryani, I., Nirmala, K., \& Hastuti, Y. P. (2015). Karakteristik Lingkungan Hutan Mangrove di Desa Mojo, Ulujami, Pemalang Sebagai Acuan Kegiatan Aquasilviculture Kepiting Bakau Scylla serrata. Institut Pertanian Bogor.

Tumisem. (2012). Pendidikan Lingkungan Berbasis Ekologi Perairan Melalui Kepramukaan. Yogyakarta: Pustaka Pelajar.

Zalukhu, S. (2012). Ekowisata: panduan dasar pelaksanaan. Nias: Dinas Pariwisata dan Kebudayaan Kabupaten Nias. 